\title{
N-S crustal shear system in the Bundelkhand massif: A unique crustal evolution signature in the northern Indian peninsula
}

\author{
S P Singh ${ }^{1, *}$ and A R Bhattacharya ${ }^{2}$ \\ ${ }^{1}$ Department of Geology, Institute of Earth Sciences, Bundelkhand University, Jhansi 284 001, India. \\ ${ }^{2}$ Centre of Advanced Study in Geology, University of Lucknow, Lucknow 226 00\%, India. \\ *Corresponding author. e-mail: spsinghbu@rediffmail.com
}

MS received 1 December 2016; revised 26 May 2017; accepted 28 May 2017; published online 4 December 2017

The Bundelkhand massif, located in the northern part of the Indian shield, is a poly-deformed and poly-metamorphic terrain. This paper reports a new shear system developed throughout the massif in the form of $\mathrm{N}-\mathrm{S}$ trending quartz veins that are sometimes quartzo-feldspathic and rarely granitic in composition. The veins are vertical and commonly occur in conjugate sets. This tectono-magmatic event appears to represent the youngest shear system of the massif as it cross-cuts all the earlier shear systems (E-W, NE-SE and NW-SE). Emplacement of this N-S vein system may have taken place due to extensional processes that developed some cracks along which siliceous magma was vertically emplaced. The complete absence of signature of the N-S event from the surrounding sedimentary cover of Vindhyan Supergroup, Bijawar and Gwalior Groups suggests that this shear system is pre-tectonic to the nearly E-W trending passive basins developed at the margins of the Bundelkhand craton. Further, several workers have considered the Bundelkhand massif as a part of the Aravalli craton. However, due to the absence of N-S, as well as the other (i.e., E-W, NW-SE and NW-SE), tectonic fabrics of the Bundelkhand massif in other cratons of the Peninsular India, and vice versa, makes the Bundelkhand block a separate and unique craton of its own and is not part of the Aravalli craton.

Keywords. Bundelkhand craton; shear system; extensional tectonics; conjugate shear; crustal evalution.

\section{Introduction}

Most cratons are characterized by complex structural-magmatic history. They have experienced several cycles of deformation and magmatism and in most cases both these processes occurred together (Mareschal et al. 1995; Drury et al. 1984). Superimposed on these are events of crustal scale shearing and invariably these shearing events are associated with either magmatism or metamorphism or both (Chardon et al. 2008; Chetty 2010). As yet, our information on
Precambrian shear systems is highly meagre to negligible.

The Indian peninsula is characterized by a few cratons each of which has its own structuralmagmatic setup (Radhakrishna 1989; Naqvi 2005; Sharma 2009). Also each of these is characterized by the presence of some shear systems (Chetty 2010; Mishra and Ravi Kumar 2014). As yet our knowledge on these shear systems is meagre. This paper reports a new crustal scale shear system in the Bundelkhand massif of central India. 


\section{The Bundelkhand craton}

The Bundelkhand massif is located in the northern part of the Indian shield (figure 1) and covers about $26,000 \mathrm{~km}^{2}$ area in central India. It occurs as a semicircular outcrop and mostly consists of MesoArchaean gneisses, Late-Archaean greenstone belt and Neo-Archaean Bundelkhand granitoids (Basu 1986; Sarkar et al. 1996; Sharma 2000; Mondal et al. 2002; Kaur et al. 2014, 2016). Structurally the Bundelkhand craton exposes a poly-deformed and poly-metamorphic terrain (Bhattacharya 1985, 1986; Roday et al. 1995).

The massif represents the culmination of a long period of ancient structural, tectonic, magmatic and geothermal cycles of several episodes that may have been operative from Archaean to early Proterozoic (Mohan et al. 2012; Singh 2012). The development of giant quartz reefs and mafic dike swarms of early Proterozoic (Rao et al. 2005; Basu 2007; Pati et al. 2007; Bhattacharya and Singh 2013) into the massif represent the end phase of stabilization and might be the final outcome and growth of Archaean crust transformation into Bundelkhand craton on the larger domain (Singh and Dwivedi 2015; Ray et al. 2016). The prolonged deformation history in the late Archaean to early Proterozoic times has produced complex structures in the internal domain of the massif that have left numerous signatures in the rocks of the region on various scales.

The quartz reefs (NE-SW) and the mafic dike swarms (NW-SE) are persistently present which were developed subsequent to the stabilization of the massif. The greenstone belt trending $\mathrm{E}-\mathrm{W}$ occurs together with the Meso-Archaean gneisses and is mainly exposed in the central zone of the massif and is related to the $\mathrm{E}-\mathrm{W}$ vertical shear system (Singh and Bhattacharya 2010). The granites are the most dominating constituent (about 70\%). The grey granites are mainly present in the northern part while the pink granite occurs in the southern part of the massif (Basu 2010; Ray et al. 2016).

Singh et al. (2007) suggested that the Bundelkhand Gneissic Complex (BnGC) is the oldest unit of the massif that comprises high-grade metamorphics of ortho- and para-gneisses including the amphibolites and TTGs overlain by low-grade metamorphic rocks of greenstone belts of metasedimentaries and metavolcanics. Thereafter, the Archaean crust of Bundelkhand was subjected to large scale acidic magmatism known as Bundelkhand Granitoid (BG) in the Late Archean/NeoArchrean times (2582-2515 Ma) (Mondal et al. 2002; Kumar et al. 2010; Kaur et al. 2016). This magmatism is mainly responsible for the
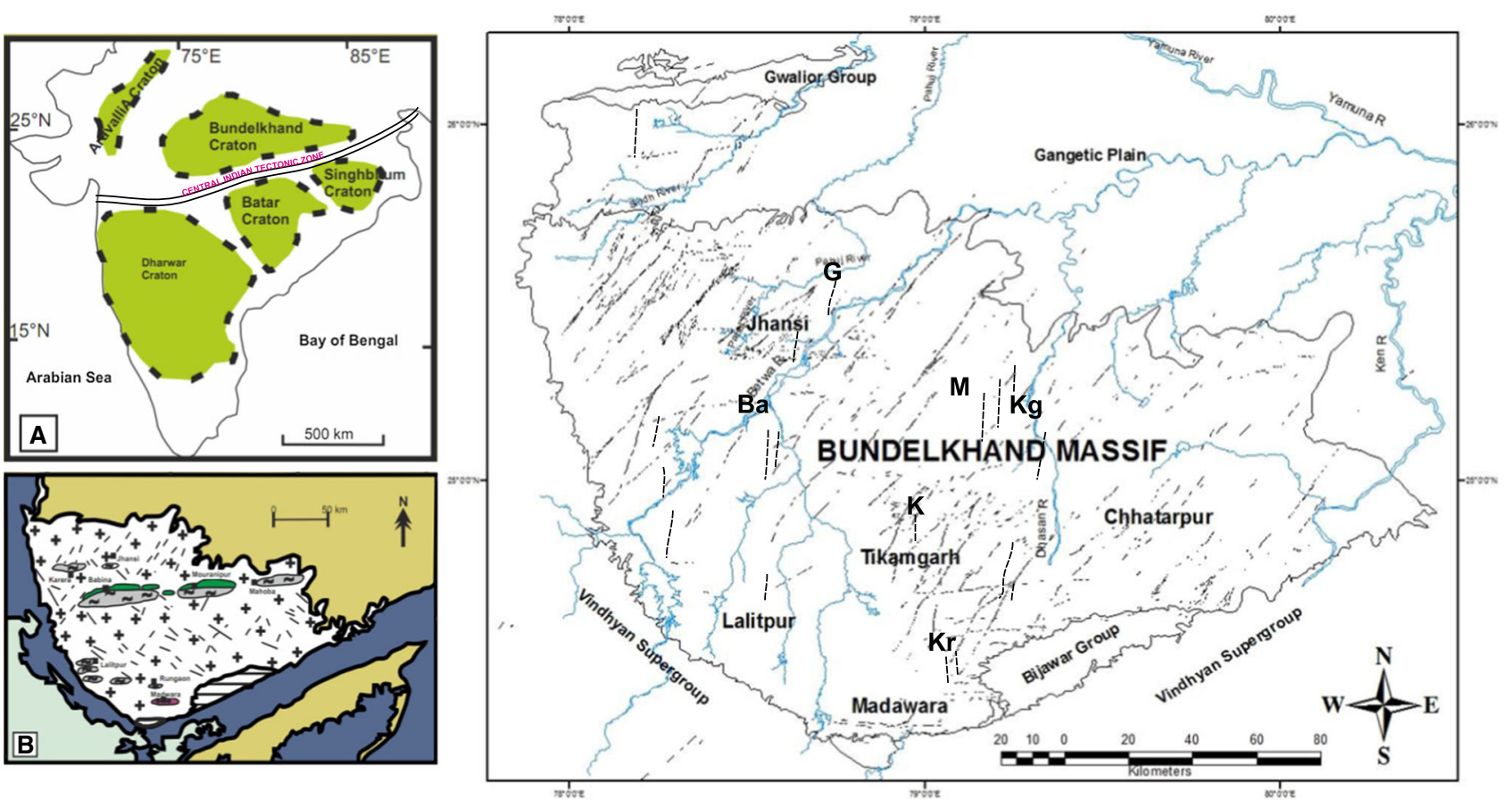

Figure 1. Bundelkhand craton showing different linear fabrics and shear systems (modified after Bhattacharya and Singh 2013). Inset shows the assembly of the cratons of the Indian shield. G: Garmau; M: Mauranipur; Kg: Khilarigaon; Kr: Karitoran; K: Kari; Ba: Babina. 
rapid crustal growth and tectonic processes of the Archaean crust and transformed the massif into a stable craton. Thereafter, the Bundelkhand craton was subjected to several episodes of deformation and magmatism such as persistent occurrence of giant quartz reefs, emplacement of granite porphyry and mafic dikes. These are related to the different shear systems (Bhattacharya and Singh 2013).

\section{Bundelkhand shear system}

In the light of our detailed geological studies of the massif (Singh and Bhattacharya 2010; Bhattacharya and Singh 2013) at least three major shear events, named here as BS1, BS2 and BS3, have been identified (table 1).

\subsection{The $E-W$ shear system}

The earliest (BS1) is an E-W shear system that generally affected the rocks of central region of the complex (Singh and Bhattacharya 2010; Bhattacharya and Singh 2013). This is a vertical shear system identified by a linear zone of mylonites showing vertical foliation. The shear zones extend over a length of about $150 \mathrm{~km}$ in the central part of the massif and occur as scattered outcrops. Individual shear zones continue for a strike length up to $3 \mathrm{~km}$ and a width up to $200 \mathrm{~m}$. The shear system is exposed in the form of isolated, ductile shear zones trending $\mathrm{E}-\mathrm{W}$ and is associated with the evolution of greenstone belt of the massif.

\subsection{The NE-SW shear system}

The NE-SW trending quartz reefs have been considered to constitute the second major shear system (BS2) of the massif (Bhattacharya and Singh 2013). The reefs are vertical structures that rise about 100-175 $\mathrm{m}$ above the surrounding ground surface. The length of individual outcrops varies from about $300 \mathrm{~m}$ to tens of kilometres and the width varies from about $20 \mathrm{~m}$ to about $100 \mathrm{~m}$. It is suggested that the quartz reefs represent

Table 1. Shear systems in the Bundelkhand massif and their charactersistics.

\begin{tabular}{|c|c|c|c|}
\hline Shear system & Charactersistics & Host rocks & Mechanism \\
\hline $\mathrm{E}-\mathrm{W}(\mathrm{BS} 1)$ & $\begin{array}{l}\text { Vertical shear system } \\
\text { with mylonites }\end{array}$ & $\begin{array}{l}\text { Feldspathic gneiss, } \\
\text { garnet-sillimanite gneiss, } \\
\text { TTGs, biotite gneiss, } \\
\text { quartzite, metavolcanics, } \\
\text { amphibolites and grey } \\
\text { granite }\end{array}$ & $\begin{array}{l}\text { Vertical shear dominated } \\
\text { by compressional } \\
\text { tectonics }\end{array}$ \\
\hline NE-SW (BS2) & $\begin{array}{l}\text { Quartz reefs and } \\
\text { injection of quartz } \\
\text { veins, granite } \\
\text { porphyry }\end{array}$ & $\begin{array}{l}\text { Pink and grey granites, } \\
\text { biotite granite, } \\
\text { amphibolites, gneisses, } \\
\text { TTGs, metavolcanics } \\
\text { and metasediments of } \\
\text { greenstone belt }\end{array}$ & $\begin{array}{l}\text { Initially extensional } \\
\text { tectonics followed by } \\
\text { acid magmatism and } \\
\text { strike-slip movements }\end{array}$ \\
\hline NW-SE (BS3) & $\begin{array}{l}\text { Mafic dikes and } \\
\text { swarms, rarely } \\
\text { massive quartz veins } \\
\text { and ultrapotassic } \\
\text { granites }\end{array}$ & $\begin{array}{l}\text { Quartz reefs, biotite } \\
\text { granite, amphibolites, } \\
\text { gneisses, pink and grey } \\
\text { granites, TTGs, } \\
\text { metasediments and } \\
\text { metavolcanics of } \\
\text { greenstone belt }\end{array}$ & $\begin{array}{l}\text { Dominated by extensional } \\
\text { tectonism followed by } \\
\text { basic magmatism; } \\
\text { occasionally strike-slip }\end{array}$ \\
\hline $\mathrm{N}-\mathrm{S}(\mathrm{BS} 4)$ & $\begin{array}{l}\text { Quartz veins, } \\
\text { occasionally } \\
\text { quartzofeldspathic } \\
\text { and granitic veins }\end{array}$ & $\begin{array}{l}\text { Gneisses, granites, } \\
\text { metavolcanics, } \\
\text { amphibolites, } \\
\text { quartzo-feldspathic } \\
\text { gneisses, mafic dikes, } \\
\text { quartz reefs and rocks of } \\
\text { BS1, BS2 and BS3 }\end{array}$ & $\begin{array}{l}\text { Initially extensional } \\
\text { tectonism with } \\
\text { development of fractures } \\
\text { and conjugate fractures } \\
\text { followed by injection of } \\
\text { silica veins }\end{array}$ \\
\hline
\end{tabular}


strike-slip dominated vertical to sub-vertical shear system with dominantly sinistral sense of shear (Bhattacharya and Singh 2013).

\subsection{The NW-SE shear system}

The third major shear system (BS3) is represented by the NW-SE trending swarms of basic dikes (Bhattacharya and Singh 2013) emplaced in the fractures developed due to extensional processes followed by strike-slip shearing. Like quartz reefs, the basic rocks also occur as scattered outcrops in more or less a linear fashion. Individual outcrops vary in length from tens of metres to about $5 \mathrm{~km}$ and in width from a few metres to about $100 \mathrm{~m}$.

All the three major shear systems of the Bundelkhand craton are associated with some form of magmatic activity. As such we consider all these shearing events as tectono-magmatic events of the Bundelkhand massif.

\section{The $\mathrm{N}-\mathrm{S}$ shear system}

In addition to the above three crustal shear systems, a fourth major tectono-magmatic event of the Bundelkhand craton, designated here as BS4, is being reported in this paper for the first time. This shear system is present mainly in the form of $\mathrm{N}-\mathrm{S}$ trending quartz veins that are sometimes quartzo-feldspathic and rarely granitic in composition and is developed throughout the craton persistently. They range in length from a few metres to kilometres. Generally, these are continuous but occasionally their continuity is broken especially when their length is hundreds of metres. Their width varies from about 1 to about $20 \mathrm{~m}$. The magmatic veins occur both as a single unit as well as a mass of several smaller veins occurring together (figure $2 \mathrm{~b}$ ) and all of these are typically oriented N-S (figure $2 \mathrm{a}$ and $\mathrm{d}$ ).

The $\mathrm{N}-\mathrm{S}$ veins cross-cut all the earlier shear systems including E-W, NE-SW and NW-SE. This appears to be a characteristic feature of this vein system. We have collected field evidences of cross-cutting relations by the $\mathrm{N}-\mathrm{S}$ vein in all the rock types they occur (figures 2 and 3 ). As such, the $\mathrm{N}-\mathrm{S}$ shear system could be considered as the youngest tectono-magmatic event of the Bundelkhand massif.
Our study from the entire Bundelkhand massif reveals that the $\mathrm{N}-\mathrm{S}$ vein system shows the following characteristic features: (1) they are vertical, (2) the veins bear cross-cutting relations with, and displace, the earlier shear systems, i.e., BS1, BS2 and BS3 (figure 3d), (3) the veins occur in conjugate sets at several places with angle varying from $30^{\circ}$ to $60^{\circ}$ and (4) occasionally show evidence of a north-south shear in the foliations of the adjacent rocks (figure $3 \mathrm{~b}$ and c) that include practically all the major rock types of the massif, viz., granites, gneisses, TTGs, greenstones, metavolcanics, quartzites, etc.

If we integrate the details of these three shear systems, we get a unique structural-tectonic pattern of the Bundelkhand massif in space and time. From above, it appears that the various shear systems constitute an integral part of the Bundelkhand craton. Nature of these shear systems continues to change from ductile, ductile-brittle and to brittle shear zones in space and time. In the light of our observations, the nature of the four crustal shear systems show a change from ductile to brittle types with time. Thus the earliest, i.e., $\mathrm{E}-\mathrm{W}$, shear system was highly ductile while the later systems (NE-SW and NW-SE) were brittleductile to brittle. The N-S system also represents a signature of shallow, near-surface fracture system and, as such, the deformation pattern could be related to the brittle regime.

\section{Geometry of the $\mathrm{N}-\mathrm{S}$ shear system}

The $\mathrm{N}-\mathrm{S}$ vein system under study is dominantly in the form of siliceous magmatic intrusions emplaced vertically. The emplacement may have taken place along some N-S trending fractures developed due to extensional processes that affected this part of the shield subsequent to the stabilization of the Bundelkhand massif and its signatures are not recorded in the surrounding sedimentary cover (Vindhyan Supergroup, Bijawar Group and Gwalior Group), outside the massif. Conjugate nature of the vein system represents signatures of conjugate fractures that may have developed during the formation of the fractures. The vein system thus developed had to make its way up in the crust thus cutting across, and displacing, the earlier shear systems, viz., the E-W (BS1), NE-SW (BS2) and NW-SE (BS3) shear systems (figures 2d and $3 \mathrm{~d}$ ). The vein system under study can thus be described to constitute a shear system (figure 3a) 

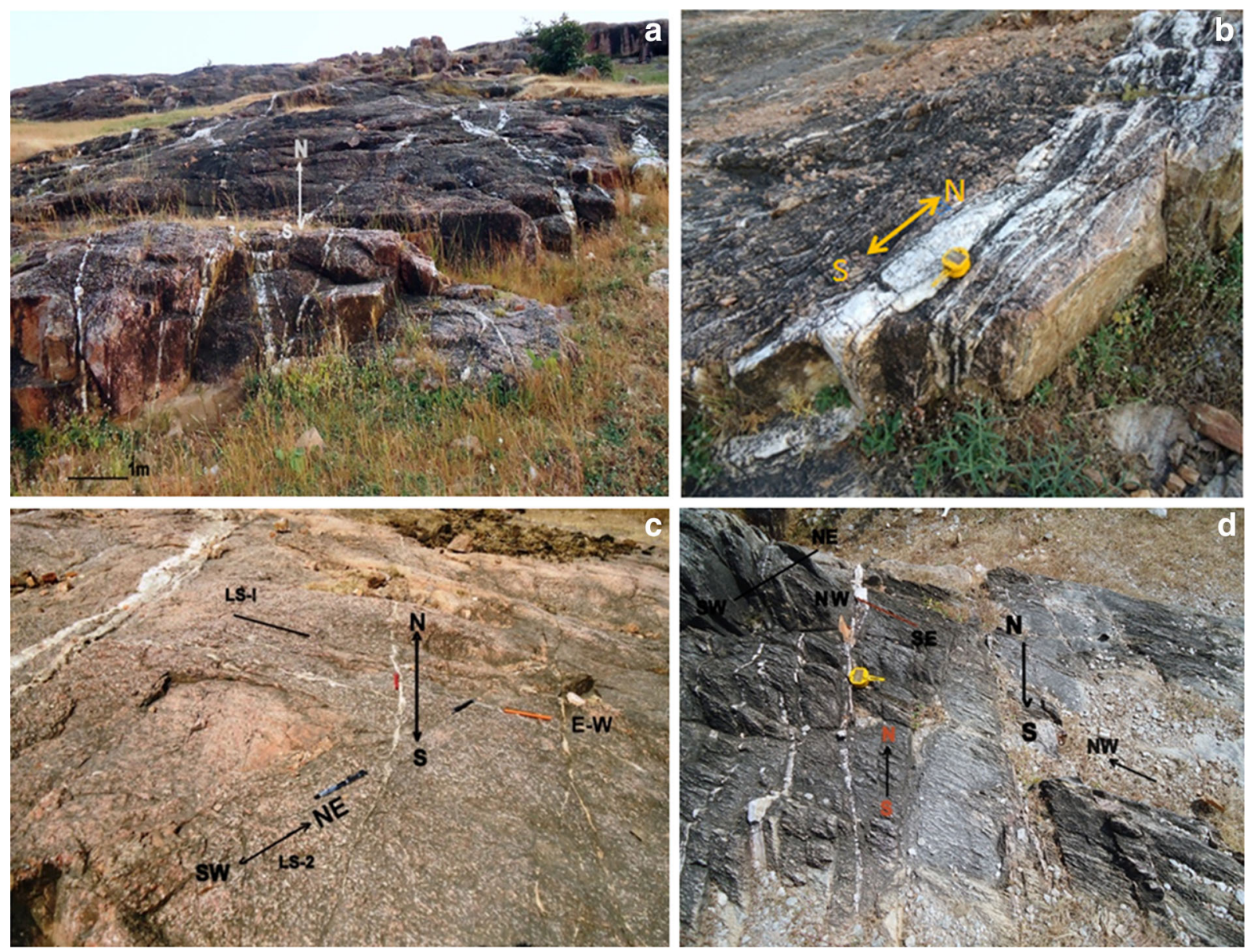

Figure 2. Photographs of N-S shear system showing field relations. (a) An outcrop of N-S shear system developed in the pink granite. (b) A swarm of vertical veins in the N-S trending shear system passing through pink granite. $\mathrm{N}$ is towards the lower left corner of the photographs A and B. (c) The N-S shear system displacing the older E-W as well as NE-SW shear systems. (d) The $\mathrm{N}-\mathrm{S}$ shear system displacing the older E-W shear system.

which is developed in the various rock types of the Bundelkhand massif. Therefore, this vein system can be described as a major N-S crustal shear system of the massif. This system shows both ductile and brittle features (figure $3 \mathrm{~b}$ and $\mathrm{c}$ ) thus suggesting that it must have developed at depth and continued to extend up in the crust up to the shallow levels. On the basis of the above-mentioned evidences, the $\mathrm{N}-\mathrm{S}$ shear system can be considered to constitute an independent shear system developed subsequent to BS1, BS2 and BS3 and it may represent the youngest tectono-magmatic event in the massif. At a few places, the veins show evidences of shearing in the north-south directions that left its signatures in the foliations of the host rocks on either side of the veins (figure 3c). However, because of limited evidences, the effects of this shearing on other shear systems could not be assessed at this stage.

\section{Mechanisms of conjugate vein system}

In the $\mathrm{N}-\mathrm{S}$ shear system, the most common trend of the veins is approximately $\mathrm{N}-\mathrm{S}$. Their orientation varies between $\mathrm{N} 15^{\circ} \mathrm{E}-\mathrm{S} 15^{\circ} \mathrm{W}$ and $\mathrm{N} 5^{\circ} \mathrm{W}-\mathrm{S} 5^{\circ} \mathrm{E}$ and has been plotted on a rose diagram (figure 4) that gives a mean orientation of $\mathrm{N} 4^{\circ} \mathrm{E}$. The conjugate veins are also vertical and the conjugate angle varies from $30^{\circ}$ to $60^{\circ}$. The conjugate veins are both symmetrically as well as asymmetrically disposed with respect to the main $\mathrm{N}-\mathrm{S}$ vein. This suggests that the stress pattern during the formation of conjugate veins was not uniform and continued to vary with time during the emplacement of the veins. In this paper, we consider all the $\mathrm{N}-\mathrm{S}$ veins and the associated conjugate veins to represent a particular dike system or swarm because they vertically cut across all the rock types. These may have intruded along some fractures that may have formed due 

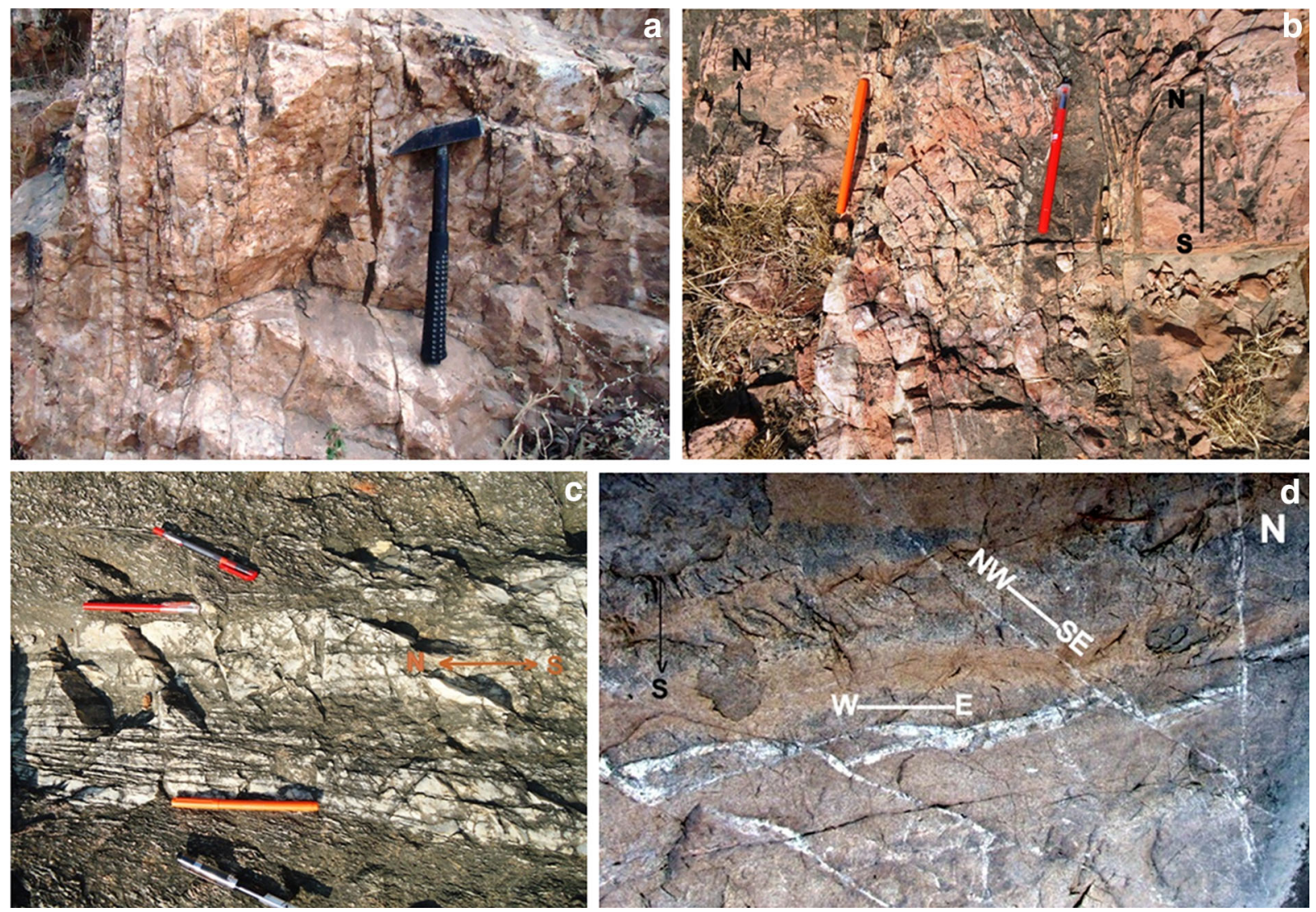

Figure 3. Field photographs showing the orientation of the N-S shear system with respect to the earlier shear systems (E-W and NE-SW). Note the N-S veins cut across all the earlier shear systems.

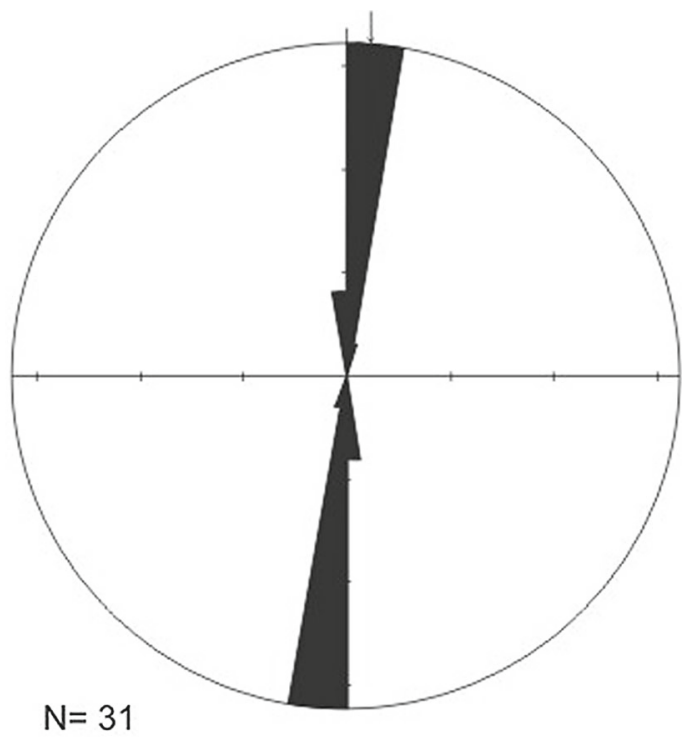

Sector angle $=10^{\circ}$

Scale: tick interval $=20 \%$ [6.2 data]

Maximum $=64.5 \%$ [20 data]

Mean Resultant dir'n $=004-184$

$\left[95 \%\right.$ Confidence interval $\left.= \pm 3^{\circ}\right]$

Figure 4. Orientation of 31 veins as plotted on a rose diagram. The mean orientation obtained is $\mathrm{N} 4^{\circ} \mathrm{E}-\mathrm{S} 4^{\circ} \mathrm{W}$. to some extensional processes that the region may have undergone. Jolly and Sanderson (1997) suggested that for a fracture to open, the fluid pressure must exceed the normal stress acting on the fracture. Thus, the magmatic fluid of the $\mathrm{N}-\mathrm{S}$ fractures must have had high fluid pressure first to open the fractures and then to fill them with the fluid.

Now the question arises as how the channels that supplied the silica fluids came into existence. As per suggestion of Jolly and Sanderson (1995), we consider the channels could represent some preexisting fractures and the variations in thickness and spacing of the silica veins could result from changes in the character of the magma flow. Since on a regional basis the veins and their conjugate vein system are always associated together, it appears that the conjugate fracture system may have developed synchronously with the formation of the N-S vein system (see Speight et al. 1982).

At this stage, it is however difficult to ascertain the orientation of stresses for the conjugate system. The main reason is that the Bundelkhand craton itself is petrologically heterogeous and includes tectonic fabrics of different orientations. As such 
the craton poses some mechanical constraints for formation of conjugate fracture pattern. Perhaps because of this, the occurrence of conjugate veins is sparse. Ramsay and Huber (1987) presented a model with three different mechanisms for formation of conjugate fractures close to the surface of the earth. Of these, it is possible that the normal faulting mechanism could be more applicable for the $\mathrm{N}-\mathrm{S}$ shear system of the Bundelkhand craton. It therefore seems possible that the conjugate fractures, along which quartzo-feldspathic material was emplaced as veins, may have formed under conditions when $\sigma_{3}$ constituted the east-west oriented maximum tensile stress while $\sigma 1$ constituted the upward-directed minimum tensile stress. The $\mathrm{N}-\mathrm{S}$ fractures thus may have formed when the craton was under the influence of east-west directed extensional tectonics $\left(\sigma_{3}\right)$ while $\sigma_{1}$ was provided by rapid exhumation of the craton. The rate of exhumation varied markedly in space and time and

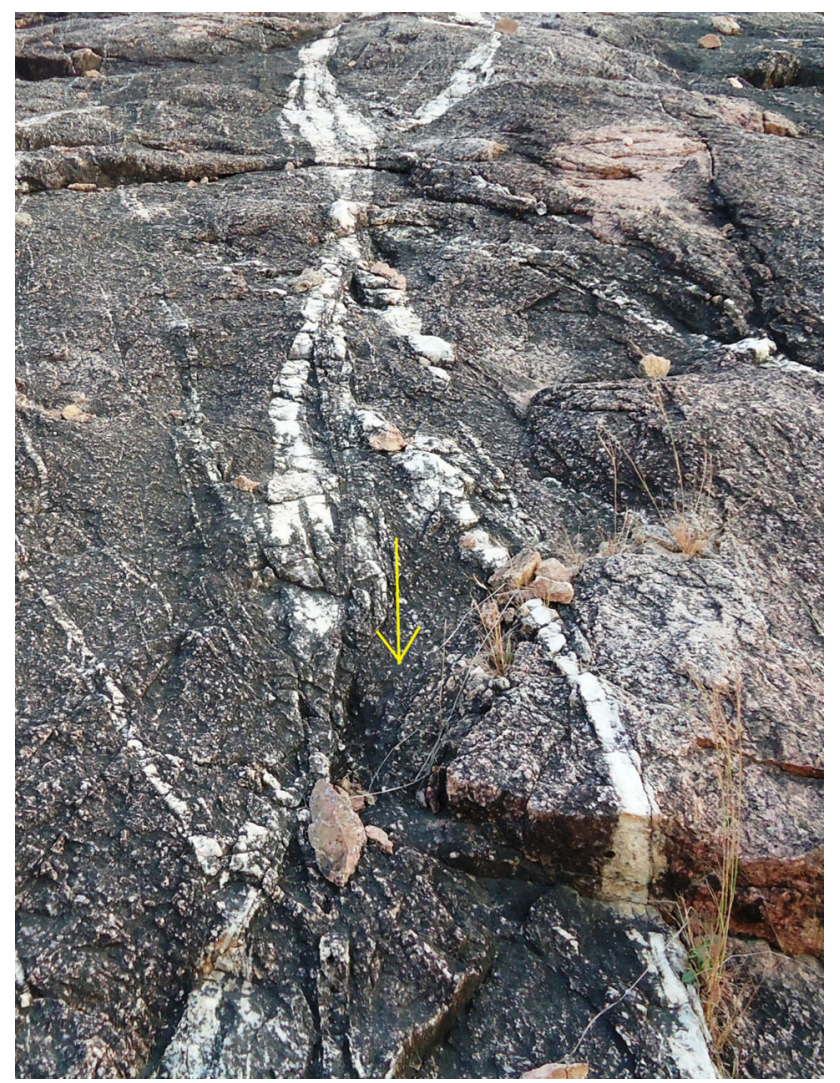

Figure 5. Close-up photograph of conjugate veins. Two conjugate vein systems can be seen in the photograph. The smaller one, on the top, is symmetrical with respect to the main N-S vein. The other one at the bottom, on the other hand, is asymmetrical and one arm is slightly curved also. This is due to the changes in the local stress conditions (see text for details). The arrow head points north. Location Mauranipur. that is why the development of conjugate system is localized in some areas only.

Under the influence of the above-mentioned set up of stresses, the conjugate veins may have formed by the intrusion of siliceous magma in the fractures. The intrusive nature of the magma was strongly influenced by the local stresses. As a result, the magma had to deviate from the main upwarddirected motion to maintain a trend that is normal to the minimum principal stress, i.e., a diversion towards the maximum principal stress $\left(\sigma_{1}\right)$ as has been suggested for the Mull dikes of Scotland (Jolly and Sanderson 1995). It therefore appears that the conjugate system may represent the left-right diversion, though locally, of the main vein (figure 5 , upper veins) towards the direction of the maximum principal stress. At places where the local stress pattern was heterogenous at the point of conjugacy, or the lithology was hetrogenous, the two arms of the conjugate veins are not always symmetrical with respect to the main vein. Because of this, the two arms are sometimes asymmetrical and occasionally one or both arms are curved also (figure 5, lower veins). The formation of the conjugate pattern at a particular point is thus the result of the tendency of diversion of the vertically rising magma sideways.

\section{Discussion}

Considering the fact that the Bundelkhand massif is a part of the Indian shield, we find that the tectonic fabric of this massif bears several dissimilarities with those of the adjoining cratons (figure 1). In central India, there is a large $\mathrm{E}-\mathrm{W}$ trending tectonic feature called the Central Indian Tectonic Zone (CITZ) developed in the Proterozoic times (Roy and Prasad 2003; Sharma 2009; Santosh 2011). It is believed to be a major amalgamation of several cratonic blocks of the Indian shield in Proterozoic times (Naqvi 2005). The Bundelkhand terrain is located north of this belt. However, none of the tectonic elements/fabrics of CITZ are represented in the Bundelkhand massif. Another landmass that evolved west of the Bundelkhand massif, i.e., the Aravalli craton, shows a dominant NE-SW trending tectonic fabric (Roy 2001; Roy and Jakhar 2002; Sharma 2000). Northwest of the Aravallis exists a NNE-SE trending fabric (Delhi Supergroup). The Singhbhum craton, another Archaean nucleus to the south of the Bundelkhand massif, is in general characterized 
by an $\mathrm{E}-\mathrm{W}$ trend and is disposed mostly in an arcuate shape (Mazumdar et al. 2012). The Himalayan tectonic belt, occurring north of the Bundelkhand massif, includes Precambrian sequences at different levels, has a distinct E/ESE-W/WNW fabric and has altogether a different tectonic identity in the Indian subcontinent due to its involvement in the India-Asia plate collision in the Tertiary times. It therefore appears that none of the tectonic elements/fabrics of the above tectonic blocks are identified in the Bundelkhand massif in time and space and vice versa.

Several researchers (Naqvi and Rogers 1987; Sharma 2009; Naqvi 2005 and the references therein) have considered the Bundelkhand massif as a part of the Aravalli craton and the granites in the Bundelkhand massif are equivalent to the Berach granite of Aravalli's. Our recognition of the $\mathrm{N}-\mathrm{S}$ shear system, together with the E-W, NE-SW and NW-SE shear systems, makes the Bundelkhand massif unique of its kind in the Indian peninsula. These fabrics, as well as the E-W orientation of the litho-formations and their fabrics, e.g., foliation trend, etc., are not represented in none of the above-mentioned tectonic/cratonic blocks. All these appear to make the Bundelkhand craton an independent identity in space and time. Therefore, the Bundelkhand massif may be considered as an independent craton of the Indian peninsular shield and the tectonic consequences and implications of the four different types of crustal shear systems (E-W, NE-SW, NW-SE, N-S) recognized by us need to be addressed in the larger context of the Indian shield.

\section{Acknowledgements}

ARB thanks the Head, Centre of Advanced Study in Geology, University of Lucknow, for providing working facilities. We would also like to thank the two anonymous reviewers of this paper for their constructive comments and suggestions. Finally, thanks to Dr A K Verma for his help during preparation of the manuscript.

\section{References}

Basu A K 1986 Geology of parts of the Bundelkhand granite massif, central India; Rec. Geol. Surv. India Part II 117 $61-124$.

Basu A K 2007 Role of the Bundelkhand granite massif and the Son-Narmada mega fault in Precambrian crustal evolution and tectonism in central and western India; $J$. Geol. Soc. India 70 745-770.

Basu A K 2010 Precambrian geology of Bundelkhand terrain, central India and adjacent part of western India; J. Econ. Geol. Georesour. Manag. 7 1-53.

Bhattacharya A R 1985 Some unusual strain relations in elliptically deformed xenoliths and feldspar porphyroblasts; Zeitschr. Geol. Wissen. Berlin 13 689-697.

Bhattacharya A R 1986 Wavelength-amplitude characteristics of polyphase folds in the Precambrian Bundelkhand Complex, India; Tectonophys. 128 121-125.

Bhattacharya A R and Singh S P 2013 Proterozoic crustal scale shearing in the Bundelkhand massif with special reference to quartz reefs; J. Geol. Soc. India 82 474-484.

Chardon D, Jaynanda M, Chetty T R K and Peucat J J 2008 Precambrian continental strain and shear zone patterns: The South Indian case; J. Geophys. Res. 113 B08402, https://doi.org/10.1029/2007JB005299.

Chetty T R K 2010 Structural architecture of the northern composite terrene, Eastern Mobile Belt Indian Implication for Gonwana tecotnics; Gondwana Res. 18 565-582.

Drury S A, Harris N B W, Holt R W, Reevessmith G J and Wightoman R T 1984 Precambrian tectonics and evolution of south India; J. Geol. 92 3-20.

Jolly R J H and Sanderson D J 1995 Variation in the form and distribution of dykes in the Mull swarm, Scotland; J. Struct. Geol. 17 1543-1557.

Jolly R J H and Sanderson D J 1997 A Mohr circle construction for the opening of a pre-existing fracture; J. Struct. Geol. 19 887-892.

Kumar S, Raju S, Pathak M and Pandey A 2010 Magnetic susceptibility mapping of felsic magmatic lithounits in the central part of Bundelkhand Massif, central India; J. Geol. Soc. India 75 539-548.

Kaur P, Armin Z and Chaudhari N 2014 Charecterization of $\mathrm{U}-\mathrm{Pb}-\mathrm{Hf}$ isotopes records of the $3.55 \mathrm{Ga}$ felsic crust from Bundelkhand craton, northern India; Precamb. Res. 255 236-244.

Kaur P, Zehb A, Chaudhri N and Eliyasa N 2016 Unraveling the record of Archaean crustal evolution of the Bundelkhand Craton, northern India using $\mathrm{U}-\mathrm{Pb}$ zircon-monazite ages, Lu-Hf isotope systematics, and whole-rock geochemistry of granitoids; Precamb. Res., https://dx.doi.org/10. 1016/j.precamres.2016.06.005.

Mareschal M, Kellett R L, Kurtz R D, Ludden J N, Ji S and Bailey R C 1995 Archean cratonic roots, mantle shear zones and deep electrical anisotropy; Nature $\mathbf{3 7 5}$ 134-137.

Mazumdar R, Van loon A J, Malik A, Reddy S M, Arima M, Altermann W, Eriksson P G and De S 2012 MesoarcheanPaleoproterozoic stratigraphic records of the Singhbhum crustal province, eastern India: Synthesis; Geol. Soc. London Spec. Publ. 365 39-49.

Mishra D C and Ravi Kumar M 2014 Proterozoic orogenic belts and rift of Indian cratons; Geosci. Frontier 5 25-41.

Mohan M R, Singh S P, Santosh M, Siddiqui M A and Balaram V 2012 TTG suite from the Bundelkhand craton central India: Geochemistry petrogenesis and implications for Archean crustal evolution; J. Asian Earth Sci. 58 $38-50$.

Mondal M E A, Goswami J N, Deomurari M P and Sharma K K 2002 Ion microprobe $207_{\mathrm{Pb}} / 206_{\mathrm{Pb}}$ ages of zircons 
from the Bundelkhand massif, northern India: implications for crustal evolution of the Bundelkhand-Aravalli protocontinent; Precamb. Res. 117 85-100.

Naqvi S M 2005 Geology and Evolution of the Indian Plate; Capital Publishing Company, New Delhi, India, 450p.

Naqvi S M and Rogers J W 1987 Precambrian Geology of India; Monographs on Geology and Geophysics, Oxford University Press, Oxford, 6 p. 223.

Pati J K, Patel S C, Pruseth K L, Malviya V P, Arima M, Raju S, Pati P and Prakash K 2007 Geology and geochemistry of giant quartz veins from the Bundelkhand Craton, central India and their implications; J. Earth Syst. Sci. $116497-510$.

Radhakrishna B P 1989 Suspected tectono-straitigraphic terrane elements in the Indian sub-continent; J. Geol. Soc. India 34 1-24.

Ramsay J G and Huber M I 1987 The Techniques of Modern Structural Geology: Folds and Fractures; Academic Press, London.

Rao J M, Poornachandra G V S, Widdowson M and Kelley S P 2005 Evolution of Proterozoic mafic dyke swarms of the Bundelkhand Granite Massif, Central India; Curr. Sci. 88 502-506.

Ray L, Nagaraju P, Singh S P, Ravi G and Roy S 2016 Radioelemental, petrological and geochemical characterization of the Bundelkhand craton, central India: Implication in the Archean geodynamic evolution; Int. J. Earth Sci. 105 1087-1107.

Roday P P, Diwan P and Singh S 1995 A kinematics model of emplacement of quartz reef and subsequence deformation pattern in the central Indian Bundelkhand batholith; Proc. Indian Acad. Sci. (Earth Planet. Sci.) 104 465-488.

Roy A and Prasad H M 2003 Tectonothermal events in Central Indian Tectonic Zone (CITZ) and its implications in Rodinia crustal assembly; J. Asian Earth Sci. 22 $115-129$

Corresponding editor: SAIBAL GuPTA
Roy A B 2001 Precambrian crustal growth: From the earliest transient crust to the assembly and breakup of supercontinent; Proc. Indian Nat. Sci. Acad. 67 438-460.

Roy A B and Jakhar S Y 2002 Geology of Rajasthan (NW India): Precambrian to Recent; Scientific Publisher (India), 421p.

Santosh M 2011 India's Paleoproterozoic legacy; Geol. Soc. London Spec. Publ. 365 263-288.

Sarkar A, Paul D K and Potts P J 1996 Geochronology and geochemistry of the Mid-Archaean trondhjemitic gneisses from the Bundelkhand craton, central India; In: Recent Researches in Geology (ed.) Saha A K, 16 76-92.

Sharma K K 2000 Evolution of Archean Plaleoproterozoic crust of the Bundelkhand craton, northern Indian shield; In: Research Highlights in Earth System Science (eds) Verma O and Mahadevan T M, DST Special Publication No. 1, Pg. Ind. Geological Congress, pp. 95-105.

Sharma R S 2009 Cratons and Folded Belts of India; Springer Publication, 319p.

Singh S P and Bhattacharya A R 2010 Signatures of Archaean E-W crustal-scale shears in the Bundelkhand Massif, central India: An example of vertical ductile shearing; Earth Sci. India 3 217-225.

Singh S P 2012 Archean geology of Bundelkhand craton, central India: An overview; Gondwana Geol. Mag. 13 $125-140$.

Singh S P and Dwivedi S B 2015 High grade metamorphism in the Bundelkhand Massif and its implications on Mesoarchean crustal evolution in central India; J. Earth Syst. Sci. 124 197-211.

Singh S P, Singh M M, Srivastava G S and Basu A K 2007 Crustal evolution in Bundelkhand area, central India; Him. Geol. 28 79-101.

Speight J, Skelhorn R, Sloan T and Knaap R 1982 The dyke swarms of Scotland; In: Igneous rocks of the British Isles (ed.) Sutherland D S, John Wiley and Sons, Chichester, pp. 449-459. 